\title{
THE SPATIAL DIFFERENTIATION OF DEVELOPMENT AND THE LEVEL OF THE FINANCIAL SITUATION OF RURAL COMMUNES OF THE SWIETOKRZYSKIE VOIVODESHIP
}

\author{
Pawel Dziekanski ${ }^{1}, \mathrm{PhD}$; Elwira Lesna-Wierszolowicz ${ }^{2}, \mathrm{PhD}$ \\ ${ }^{1}$ Institute of Law, Economics and Administration, Jan Kochanowski University in Kielce, Poland; ${ }^{2}$ West \\ Pomeranian University of Technology in Szczecin, Poland
}

\begin{abstract}
A commune is a system in which various types of relationships between individuals and groups take place. It is bound by law to provide specific services and tasks. This requires the use of certain economic, infrastructure and financial resources. Finances are therefore the basis for the implementation of public tasks and determine the conditions for local economic development. The aim of the article is to analyse the spatial disproportions of communes' development in relation to their financial situation with the use of a synthetic measure (TOPSIS) in 2012, 2014, 2017. As part of the research, data from the Regional Data Bank of the Central Statistical Office and the regional accounting office were used, which allowed to build a synthetic measure of development and financial situation. The financial situation determines the scope and level of public services and tasks performed by rural communes. It is also one of the elements of creating opportunities or barriers to the competitiveness of rural communes. As part of the research, data from the Regional Data Bank of the Central Statistical Office and the regional accounting office were used, which allowed to build a synthetic measure of development and financial situation. The financial situation determines the scope and level of public services and tasks performed by rural communes. It is also one of the elements of creating opportunities or barriers to the competitiveness of rural communes. The value of the development measure fluctuated in 2012 from 0.38 to 0.54 ; in 2017 from 0.37 to 0.63 . The best units (Strawczyn, Morawica, Sitkowka-Nowiny) in the studied area are characterized by a high position within the financial situation and good industrial function, which is supported by a well-developed infrastructure and social. These are units for which the agricultural function disappears and the industrial function significantly develops.
\end{abstract}

Key words: financial situation, development process, rural commune, Swietokrzyskie Voivodeship. JEL code: H70, H71, H72, P25, R13.

\section{Introduction}

Nowadays, the region is perceived as a zone subsystem with a spatial character. The creation of specific structures is associated with the process of organizing space, consisting in placing in it individual elements (economic, social, technical) building a given system, determining their interrelationships and relations with the natural environment (Korenik S., 1999, 51).

Ensuring a balance of economic, social and environmental goals aimed at long-term development means basing the functioning of local and regional systems on the principle of sustainable and sustainable development, should be the goal of decisions of local authorities. The use of endogenous factors in this process leads to the improvement of the general well-being of the inhabitants (Prus P., Drzazdzynska K., 2017). Local development is a multidimensional concept and is perceived as quantitative and qualitative changes taking place in the social and economic functioning of local government units (Markowski T., 2008, 9).

The financial situation includes not only the financial position, but also the self-government's ability to continue providing services and repaying liabilities. It a component of the competitiveness and responsibility of local authorities for the development and satisfaction of the needs of its inhabitants. The assessment of the financial standing of local government units allows to determine not only the efficiency of the functioning of these units, ie the ability to meet their obligations, but also the opportunity to improve the quality standard of services they provide to local communities (Dziekanski P., 2016).

\footnotetext{
1 pdziekan@interia.eu

2 elwira.lesna@zut.edu.pl
} 


\section{Data / Methods}

The aim of the article is to analyse the spatial disproportions in the development of rural communes in relation to their financial situation using the synthetic measure (TOPSIS). The analyses were carried out in the system of 70 rural communes in the Swietokrzyskie Voivodeship. The source material was data from the Regional Audit Chamber (Kielce branch) and the Local Data Base of the Central Statistical Office for 2012, 2014 and 2017. In the context of evaluation of development in rural communes of the Swietokrzyskie voivodship, social, economic, infrastructural and financial variables were adopted as partial measures.

In order to determine the measure of synthetic development, the following procedure was used (Dziekanski P., 2016, 2018).

1) Selection of variables describing the development and financial situation of rural communes. Variables characterized by low spatial variability and high correlation of variables were removed from the study (according to the inverted matrix method, (Malina A., 2004, 96-67).

2) The selected variables were subjected to the zero-uniformization procedure using the following formulas:

for the stimulant

$$
\begin{aligned}
& z_{i j}=\frac{\mathrm{x}_{i j}-\min _{i} \mathrm{x}_{i j}}{\max _{i} \mathrm{x}_{i j}-\min _{i} x_{i j}}, \text { where } x_{i} \in S \\
& z_{i j}=\frac{\max _{i} \mathrm{x}_{i j}-\mathrm{x}_{i j}}{\max _{i} \mathrm{x}_{i j}-\min _{i} \mathrm{x}_{i j}}, \text { where } x_{i} \in D
\end{aligned}
$$

for destimulants

where: S-stimulant, D-destimulant; $i=1,2 \ldots n ; j=1,2 \ldots n$, xij- means the value of the $j$-th characteristic for the studied unit, max - the maximum value of the $j$-th feature, min - the minimal value of the j-th feature (Dziekanski P., 2016; Mioduchowska-Jaroszewicz E., 2013, 127-140; Mlodak A., 2006).

3) A synthetic measure of development and financial situation was determined using the TOPSIS method. The value of the synthetic measure was determined for individual examined objects based on the formula (3):

$$
q_{i}=\frac{d_{i}^{-}}{d_{i}^{-}+d_{i}^{+}}, \text {gdzie } 0 \leq q_{i} \leq 1, i=1,2, \ldots, n \text {; (3)， }
$$

where: $d_{i}^{-}$- means the distance from the anti-pattern, $d_{i}^{+}$- the distance from the pattern (Wysocki F., 2010, 156-157). The indicator (3) assumes a value between [0,1]. A higher value of the indicator (close to one) means a more favourable situation of the object, a lower (near zero) weaker value (Glowicka-Woloszyn R., Wysocki F., 2016).

4) The area of rural communes in the Swietokrzyskie Voivodeship was divided into 4 quartile groups. The size of the indicator in the first group means the best unit, in the last group - the worst. The correlation between the results obtained was also verified based on the correlation coefficient (Dziekanski P., Wyszkowski A., 2018, 219-238; Wysocki F., Lira J., 2005).

\section{Research results and discussion}

Regions have become subjects of economic processes. They set the policy framework, presenting and implementing the interests of the communities concerned, taking into account local resources. Socio-economic development is a complex phenomenon and difficult to unequivocally and objectively evaluate. The environment and the economy form a network of interconnections and, acting for the benefit of the community, are interdependent and should be considered together (ZakrzewskaPoltorak A., 2011).

The development of the local government unit is spatially polarized. The actions implemented by rural communes are a combination of interrelated factors that create a multidimensional space. As Adamowicz (2003) points out, the course of basic economic processes at the local scale is shaped by 
the general economic and social system or the development policy carried out by local authorities. There are traditional factors such as: location, material resources, infrastructure, people resources, financial capital that affect the local development process. Financial resources are essential for the optimal functioning of local governments. Without sufficient levels of autonomy and resources, individuals will not be able to operate effectively. Inadequate tax structure, insufficient financial equalization system, lack of correlation between normative and actual expenditures as a result will reduce the role of local officials in the process of implementing local economic policy (Oplotnik Z., Brezovnik B., 2004).

It is worth noting that the analyses carried out by Dziekanski (2016, 2018), Churski and coauthors (2013) and Stanny (2013) show that the most important development factor, next to the location in the socio-economic space, are the local finances. Douglas and Gaddie (2002) indicate that they shape the possibilities of timely meeting financial obligations and ensuring continuity in providing services to the local community. The financial situation of rural communes is the probability that local governments will fulfil current and future financial obligations. It is also the ability to carry out public tasks (current needs of communities and development activities of rural communes) and stimulate development processes (Satola L., 2015).

Each territorial self-government unit has a range of tasks defined by law, as well as a pool of available financial resources that should secure their implementation. Satisfying the collective needs of local communities, increasing the investment attractiveness of the local government depends largely on the possessed income, both own and foreign (Bieniasz et al., 2013, 25-42).

In the Swietokrzyskie Voivodeship we can observe a clear division into the industrial north of the region and the agricultural south and east (with a gardening and fruit-growing element). The voivodeship's industry was shaped in close connection with the existing resources of rock, chemical and energy resources. The metallurgical, machine and food industries also play an important role.

A synthetic measure of the development of rural communes in the Swietokrzyskie Voivodeship in relation to the measure of financial situation is presented in Table 1 . It indicates a different level of surveyed units and changes in affiliation to the quartile group of rural municipalities over time. Evaluation of the relationship between development and financial situation is important both for the investor seeking location for the company and may have practical significance for both the authorities of the unit and the central authorities. The value of the analysed measures is shaped by economic character of the unit (industrial, agricultural), financial independence, level of own income, local taxes or expenditures, infrastructure and demographic potential.

The value of the development measure fluctuated in 2012 from 0.38 (Blizyn, the weakest unit, financial group A) to 0.54 (Morawica, the best unit, financial group A). In 2017, the rural community of Nagłowice turned out to be the weakest (0.37, financial group D), while the best was SitkowkaNowiny (0.63, financial group A). In the analyzed period, the rural commune of Strawczyn (financial situation group A) turned out to be strong. The dominant units (eg Sitkowka-Nowiny, Morawica, Strawczyn) have a service-industrial character, which is supported by well-developed infrastructure and social. They are also the leading units according to the financial situation, and their location in the vicinity of the largest centre (Kielce, the capital of the region), at the same time enhancing the changes of structures and functions performed by them for the benefit of greater multi-functionality. 


\section{Classification of rural communes in the Swietokrzyskie voivodeship according} to the measure of synthetic development in 2012, 2014 and 2017

\begin{tabular}{|c|c|c|c|c|c|c|c|c|c|}
\hline \multirow{2}{*}{ Gr } & \multirow{2}{*}{$\begin{array}{c}\text { The name of } \\
\text { the } \\
\text { commune }\end{array}$} & \multicolumn{2}{|c|}{2012} & \multirow{2}{*}{$\begin{array}{c}\text { The name of } \\
\text { the } \\
\text { commune }\end{array}$} & \multicolumn{2}{|c|}{2014} & \multirow{2}{*}{$\begin{array}{c}\text { The name } \\
\text { of the } \\
\text { commune }\end{array}$} & \multicolumn{2}{|c|}{2017} \\
\hline & & TOPSIS $_{R}$ & TOPSIS $_{\mathbf{F}}$ & & TOPSIS $_{R}$ & TOPSIS $_{F}$ & & TOPSIS $_{\mathbf{R}}$ & TOPSIS $_{F}$ \\
\hline \multirow{4}{*}{ A } & Morawica & 0.54 & A & Strawczyn & 0.56 & C & $\begin{array}{l}\text { Sitkowka- } \\
\text { Nowiny }\end{array}$ & 0.63 & A \\
\hline & $\begin{array}{l}\text { Sitkowka- } \\
\text { Nowiny }\end{array}$ & 0.53 & $A$ & Morawica & 0.55 & $A$ & Morawica & 0.58 & $A$ \\
\hline & $\begin{array}{l}\text { Miedziana } \\
\text { Gora }\end{array}$ & 0.51 & B & $\begin{array}{l}\text { Sitkowka- } \\
\text { Nowiny }\end{array}$ & 0.55 & A & Strawczyn & 0.56 & A \\
\hline & Samborzec & 0.45 & B & Rakow & 0.47 & B & Piekoszow & 0.49 & $B$ \\
\hline \multirow{4}{*}{ B } & $\begin{array}{l}\text { Skarzysko } \\
\text { Koscielne }\end{array}$ & 0.45 & C & $\begin{array}{l}\text { Ruda } \\
\text { Maleniecka }\end{array}$ & 0.47 & $\mathrm{D}$ & Wislica & 0.49 & $\mathrm{D}$ \\
\hline & Rytwiany & 0.44 & $\mathrm{C}$ & Blizyn & 0.46 & $\mathrm{D}$ & Blizyn & 0.48 & $\mathrm{D}$ \\
\hline & Sobkow & 0.44 & $\mathrm{C}$ & Bodzechow & 0.46 & $A$ & Falkow & 0.48 & $A$ \\
\hline & Szydłow & 0.44 & A & Kluczewsko & 0.46 & A & Gowarczow & 0.48 & $A$ \\
\hline \multirow{4}{*}{ C } & Tarlow & 0.43 & C & Sobkow & 0.45 & B & Wodzisław & 0.46 & C \\
\hline & Wojciechowice & 0.43 & B & Tarlow & 0.45 & $\mathrm{C}$ & Zlota & 0.46 & B \\
\hline & Falkow & 0.42 & $A$ & Gorno & 0.44 & B & Baltow & 0.45 & C \\
\hline & Imielno & 0.42 & $\mathrm{C}$ & Obrazow & 0.44 & A & Laczna & 0.45 & C \\
\hline \multirow{4}{*}{ D } & Lagow & 0.42 & B & Radoszyce & 0.44 & B & Michalow & 0.45 & A \\
\hline & Sadowie & 0.39 & B & Lagow & 0.42 & $\mathrm{C}$ & Tuczepy & 0.44 & $B$ \\
\hline & Mniow & 0.39 & $D$ & Wojciechowice & 0.42 & B & Wasniow & 0.44 & B \\
\hline & Blizyn & 0.38 & $C$ & Baltow & 0.41 & $B$ & Backowice & 0.43 & $A$ \\
\hline
\end{tabular}

Gr - quartile group; A - very good, B - good, C - weak, D - bad; TOPSIS $S_{R}$ development synthetic measure; TOPSIS financial situation synthetic measure

Source: author's calculations based on Local Data Bank of the Central Statistical Office

Diversification of the measure of synthetic development and financial situation of rural communes in the Swietokrzyskie Voivodeship in 2012, 2014 and 2017

\begin{tabular}{|l|c|c|c|c|c|c|}
\hline \multirow{2}{*}{$\begin{array}{c}\text { Measures of } \\
\text { differentiation }\end{array}$} & $\mathbf{2 0 1 2}$ & $\mathbf{2 0 1 4}$ & $\mathbf{2 0 1 7}$ & $\mathbf{2 0 1 2}$ & $\mathbf{2 0 1 4}$ & $\mathbf{2 0 1 7}$ \\
\cline { 2 - 7 } $\begin{array}{l}\text { Standard } \\
\text { deviation }\end{array}$ & 0.04 & 0.04 & 0.04 & 0.06 & 0.05 & 0.07 \\
\hline Max & 0.54 & 0.56 & 0.63 & 0.04 & 0.04 & 0.03 \\
\hline Min & 0.32 & 0.33 & 0.37 & 0.49 & 0.51 & 0.67 \\
\hline Average & 0.42 & 0.45 & 0.47 & 0.17 & 0.19 & 0.16 \\
\hline Gap & 0.22 & 0.23 & 0.26 & 0.26 & 0.28 & 0.29 \\
\hline Quartile range & 0.06 & 0.05 & 0.05 & 0.21 & 0.24 & 0.25 \\
\hline $\begin{array}{l}\text { Coefficient of } \\
\text { variation }\end{array}$ & 0.10 & 0.09 & 0.09 & 0.25 & 0.26 & 0.29 \\
\hline Asymmetry & 0.37 & 0.25 & 0.81 & 0.30 & 0.31 & 0.32 \\
\hline
\end{tabular}

Source: author's calculations based on Local Data Bank of the Central Statistical Office

Diversification of rural communes in the Swietokrzyskie Voivodeship in the analysed area of development and financial situation is stable. This is indicated both by the standard deviation (0.04 in 2012, 2014, 2017 according to the development measure, 0.06, 0.05, 0.07 according to the financial situation measure) and the coefficient of variation $(0.10,0.09,0.09$ for the measure of development, $0.22,0.20,0.24$ for the measure of financial situation). The increase in variation between rural communes in the Swietokrzyskie Voivodeship is indicated by the range, which for both 
analyzed measures increases $(0.22,0.23,0.26$ for the development measure, $0.32,0.32,0.51$ for the measure of financial situation, Table 2).

In the group of rural communes, in the Swietokrzyskie Voivodeship there is a positive correlation dependence between the synthetic measure of development and the measure of financial situation in subsequent years. The correlation value between the indicated measures was 0.219 (in 2012), 0.373 (in 2014) and 0.588 (in 2015). In the analysed period, we were dealing with convergence, and the spatial differentiation according to the examined measures was quite sTable (Table 3 ).

\section{Correlation of measures of development and financial situation of rural communes in the Swietokrzyskie Voivodeship (in 2012, 2014, 2017)}

\begin{tabular}{|l|c|c|c|c|}
\hline \multirow{2}{*}{$\begin{array}{c}\text { Synthetic measure / } \\
\text { correlation year }\end{array}$} & gamma & Spermana & tau Kendalla & Pearsona \\
\cline { 2 - 5 } & 0.730 & 0.825 & 0.685 & 0.861 \\
\hline TOPSIS $_{R} 2012-2014$ & 0.789 & 0.872 & 0.736 & 0.895 \\
\hline TOPSIS $_{R} 2014-2017$ & 0.074 & 0.095 & 0.069 & 0.219 \\
\hline TOPSIS $_{R}$ TOPSIS 2012 & 0.186 & 0.234 & 0.174 & 0.337 \\
\hline TOPSIS $_{R}$ TOPSIS 2014 & 0.290 & 0.385 & 0.273 & 0.588 \\
\hline TOPSIS $_{R}$ TOPSIS 2017 & 0.641 & 0.719 & 0.605 & 0.765 \\
\hline TOPSIS $_{F} 2012-2014$ & 0.493 & 0.586 & 0.464 & 0.710 \\
\hline TOPSIS $_{F} 2014-2017$ & & &
\end{tabular}

Correlation coefficients are significant with $p<0.050$; Source: author's calculations based on Local Data Bank of the Central Statistical Office
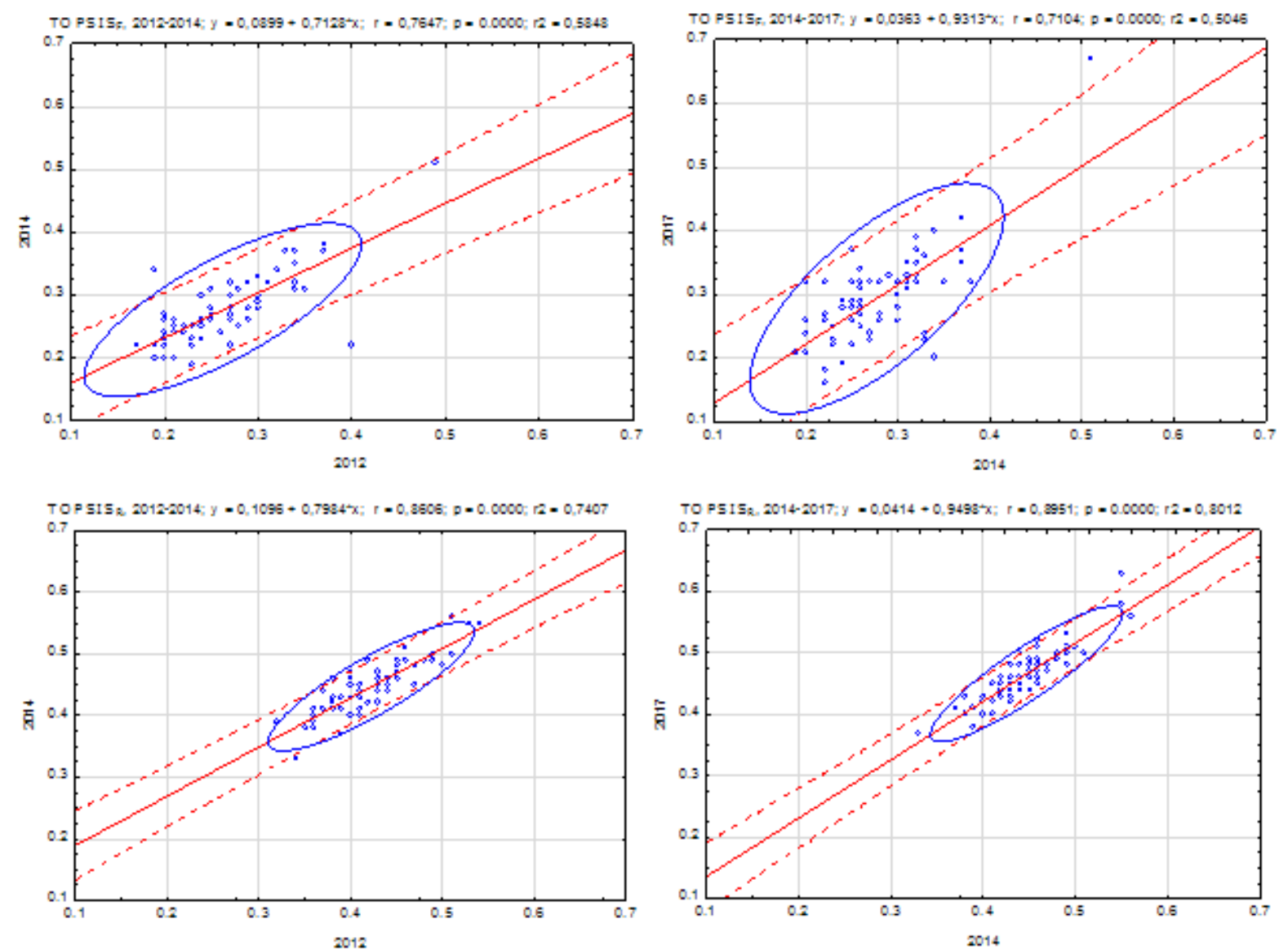

Source: author's calculations based on Local Data Bank of the Central Statistical Office

Fig. 1. The relation of synthetic measures year to year with adjustment of the regression line

Figure 1 presents correlograms describing the relationship between a synthetic measure of development and the financial situation. In the analyzed period, they were subject to convergence 
(Pearson's correlation coefficients in the analysed time interval and the level increased). The location of individual municipalities on a graph in one large group may also indicate that they are statistically similar to each other. The outliers are Morawica, Sitkowka-Nowiny, which have a developed industrial function and are located in the orbit of the region's capital (Kielce).

The analysis of the scatterplot indicates that the increasing value of the measure of development or the financial situation is accompanied by a change in the position of the points that are getting closer and closer to the straight line. The analysed synthetic measures were subject to convergence (Pearson's correlation coefficients in the analysed time interval increased from 0.219 in 2012 to 0.588 in 2017, Figure 2). Measures indicate a similar level of equipment of units in the aspect of development and financial situation as well as stability of their level over time.
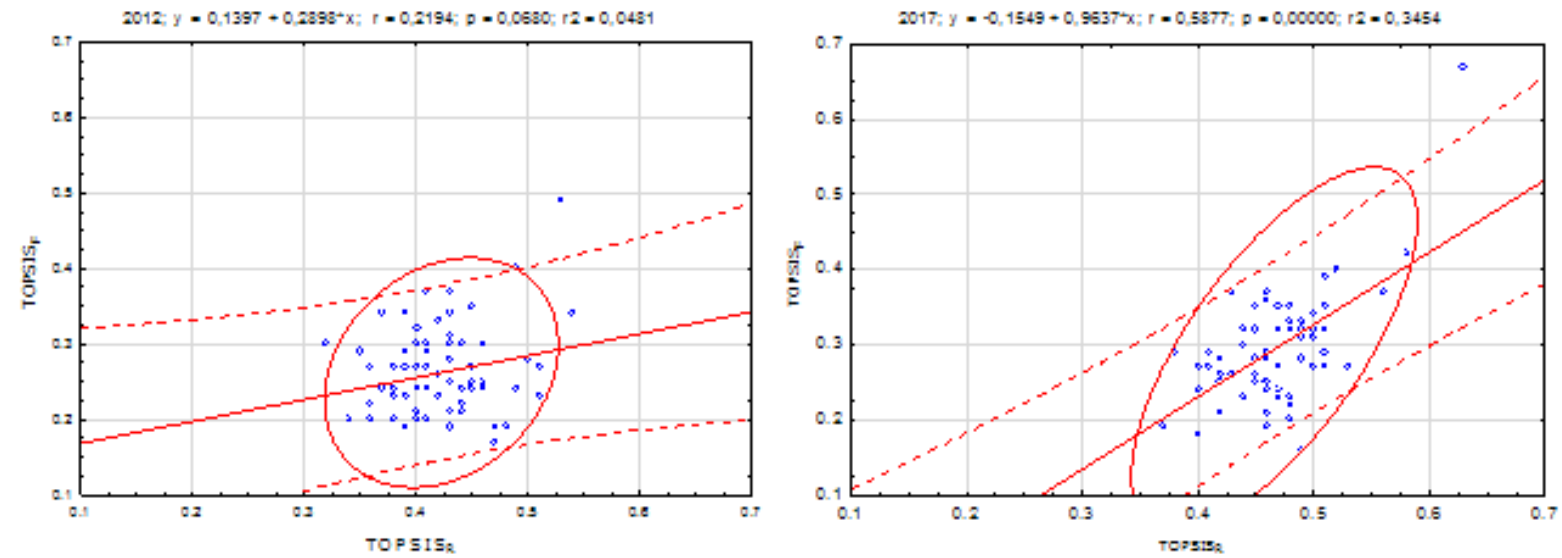

Source: author's calculations based on Local Data Bank of the Central Statistical Office

Fig. 2. Relation of synthetic measures with the adjustment of the regression lines of rural communes in the Swietokrzyskie Voivodeship (in 2012, 2014, 2017)

\section{Conclusions, proposals, recommendations}

1) The activity of local units requires making available to local self-government bodies public resources enabling organizing, supplying and financing public tasks for which local government authorities are responsible. The process of an individual's activity or its development takes place in a multidimensional space, creating a network of mutual connections and acting for the benefit of a given community. They shape measures of a financial, economic, technical infrastructure, social infrastructure, public order and safety, spatial order and ecology.

2) There is a correlation between the level of development and the financial situation of rural communes. From the financial perspective, you can make a comprehensive assessment of the functioning of the rural commune and its development opportunities. The financial situation is a derivative of the public tasks carried out by the local government. Socio-economic development is the process of transforming the economic and social environment into a place friendly to residents, allowing them to obtain decent income, ensuring access to public services, enabling participation in culture and giving a sense of agency especially in social matters and satisfying aspirations.

3) Conditions of financial standing of individuals may be shaped by the area in which they occur (e.g. location and size of territorial self-government units, available resources and natural assets, investment attractiveness) and may also be independent of it (e.g. economic fluctuations in the country and on world, state of public finances, scope of income and expenditure authority of territorial self-government units).

4) The value of the development measure fluctuated in 2012 from 0.38 (Blizyn, the weakest unit, financial group A) to 0.54 (Morawica, the best unit, financial group A). In 2017, the municipality 
of Naglowice turned out to be the weakest (0.37, financial group D), while the best was SitkowkaNowiny $(0.63$, financial group A). The best units in the studied area are characterized by good industrial function, which is supported by well-developed technical and social infrastructure.

5) The value of a synthetic measure depends on the number and type of adopted variables to be tested. It can help local authorities to assess the effectiveness of past development instruments. It allows to assess disproportions between individual units. It allows to indicate weaker and better areas of the unit's operation. In the case of low spatial aggregations, we encounter data deficits most often caused by the lack of data representativeness.

\section{Bibliography}

1. Adamowicz, M. (2003). Ksztaltowanie rozwoju lokalnego (Development of local development). In: Strategie rozwoju lokalnego. Aspekty instytucjonalne (Local development strategies. Institutional aspects), M.Adamowicz (ed.). SGGW, Warszawa, p. 11.

2. Bieniasz, A., Golas, Z., Luczak, A. (2013). Zastosowanie metody TOPSIS do oceny kondycji finansowej gmin w Polsce w 2010 roku (Application of the TOPSIS method to assess the financial condition of communes in Poland in 2010), Zeszyty Teoretyczne Rachunkowosci, t. 70 (126), SKwP, Warszawa, p. 25-42.

3. Glowicka-Woloszyn, R., Wysocki, F. (2016). Kondycja finansowa gmin wiejskich a zrodla ich dochodow w wojewodztwie wielkopolskim (Financial condition of rural communes and sources of their income in the Wielkopolskie voivodship), Stowarzyszenie Ekonomistow Rolnictwa i Agrobiznesu Roczniki Naukowe, tom XVIII, zeszyt 1.

4. Churski, P., Borowcza, A., Dolata, M., Dominik, J., Hauke, J., Perdal, R., Konecka-Szydlowska, B. (2013). Czynniki rozwoju obszarow wzrostu i obszarow stagnacji gospodarczej w Polsce (Growth factors for growth areas and areas of economic stagnation in Poland), Uniwersytet im. Adama Mickiewicza, Poznan.

5. Douglas, J.W., Gaddie, R.K. (2002). State rainy day funds and fiscal crises: Rainy day funds and the 1990-1991 recession revisited, Public Budgeting \& Finance, t. 22.

6. Dziekanski, p. (2016). Spatial Changes and Assessment of the Financial Condition of Local Government Units in the Context of the Income Structure. In: Formankova S., International Conference on Management (ICoM), Trends of Management in the Contemporary Society (Peer-Reviewed Conference Proceedings), Brno, Publisher: Mendelova univerzita v Brně.

7. Dziekanski, p. (2016). Spatial Differentiation of the Financial Condition of the Swietokrzyskie Voivodship Counties. Barometr Regionalny, Tom 14 nr 3/2016, p. 79-91.

8. Dziekanski, p. (2018). Territorialisation of Spatial Disproportions of Infrastructure and Development of Rural Areas of the swietokrzyskie voivodship. In: Proceedings of the 2018 International Conference "Economic Science for Rural Development" No 47 Jelgava, LLU ESAF, 911 May 2018, p. 73-80.

9. Dziekanski, P., Wyszkowski, A. (2018). Ocena przestrzennego zroznicowania sytuacji finansowej gmin wojewodztwa swietokrzyskiego z wykorzystaniem miary syntetycznej (Evaluation of the spatial diversity of the financial situation of the communes of the Swietokrzyskie province with the use of a synthetic measure), Optimum. Economic Studies, nr 1 (91), p. 219-238.

10. Korenik, S. (1999). Rozwoj regionu ekonomicznego na przykladzie Dolnego Slaska (The development of the economic region on the example of Lower Silesia). Wyd. Akademii Ekonomicznej im. Oskara Langego we Wroclawiu. Wroclaw

11. Malina, A. (2004). Wielowymiarowa analiza przestrzennego zroznicowania struktury gospodarki Polski wedlug wojewodztw (Multidimensional analysis of the spatial diversity of the structure of the Polish economy by voivodships), Wyd. Akademii Ekonomicznej w Krakowie, Krakow, p. 96-97.

12. Markowski, T. (2008). Teoretyczne podstawy rozwoju lokalnego i regionalnego (Theoretical foundations of local and regional development). In: Gospodarka regionalna i lokalna (Regional and local economy). ed. Z. Strzelecki, Warszawa, p. 9.

13. Mioduchowska-Jaroszewicz, E. (2013). Metody i kierunki oceny kondycji finansowej jednostek samorzadow terytorialnych (Methods and directions of assessing the financial condition of local government units), ZN US, nr 786, Finansowe, Ubezpieczenia, $\mathrm{nr}$ 64/2, p. 127-140.

14. Mlodak, A. (2006). Analiza taksonomiczna w statystyce regionalnej (Taxonomic analysis in regional statistics), Difin, Warszawa.

15. Oplotnik, Z., Brezovnik, B. (2004). Financing local government in Slovenia. Post-Communist Economies, Volume 16, Issue 4.

16. Prus, P., Drzazdzynska, K. (2017). Farmers' Assessment of Training Services and the Impact of Agricultural Advisory on Selected Developmental Factors Affecting Farming. In: Proceedings of the International Scientific Conference "Economic Science for Rural Development", Latvia University of Agriculture, Jelgava, No. 44, pp. 338-344.

17. Satola, L. (2015). Kondycja finansowa gmin w warunkach zmiennej koniunktury gospodarczej (Financial condition of communes in the conditions of a changing economic situation). Journal of Agribusiness and Rural Development, 1 (35), p. $115-123$.

18. Stanny, M. (2013). Przestrzenne zroznicowanie rozwoju obszarow wiejskich w Polsce (Spatial diversification of rural development in Poland), IRWiR PAN, Warszawa.

19. Wysocki, F. (2010). Metody taksonomiczne w rozpoznawaniu typow ekonomicznych rolnictwa i obszarow wiejskich (Taxonomic methods in recognizing economic types of agriculture and rural areas), Wyd. Uniwersytetu Przyrodniczego w Poznaniu. Poznan. 
Proceedings of the 2019 International Conference "ECONOMIC SCIENCE FOR RURAL DEVELOPMENT" No 52

Jelgava, LLU ESAF, 9-10 May 2019, pp. 248-255

DOI: $10.22616 /$ ESRD.2019.129

20. Wysocki, F., Lira, J. (2005). Statystyka opisowa (Descriptive statistics). Wyd. UP w Poznaniu, Poznan.

21. Zakrzewska-Poltorak, A. (2011). Zasoby endogeniczne jako czynnik rozwoju lokalnego i regionalnego. Studium przypadkow wybranych gmin wojewodztwa dolnoslaskiego (Endogenous resources as a factor of local and regional development. Case study of selected communes of the Lower Silesian Voivodship), PN UE we Wroclawiu, nr 152, p. 579-588. 